\title{
Managing the Early Warning Systems of Invasive Species of Plants, Birds, and Mammals in Natural and Planted Pine Forests
}

\author{
María Martínez-Jauregui ${ }^{1,2, *}$, Mario Soliño ${ }^{1,2}$, Jesús Martínez-Fernández ${ }^{1}$ and Julia Touza ${ }^{3}$ \\ 1 National Institute for Agriculture and Food Research and Technology (INIA), Forest Research \\ Centre (CIFOR), Ctra. de La Coruña km. 7.5, 28040 Madrid, Spain; solino.mario@inia.es (M.S.); \\ martinez.jesus@inia.es (J.M.-F.) \\ 2 Sustainable Forest Management Research Institute, University of Valladolid and INIA, Avda. de Madrid 57, \\ 34004 Palencia, Spain \\ 3 Environment Department, University of York, Heslington, York YO10 5DD, UK; julia.touza@york.ac.uk \\ * Correspondence: martinez.maria@inia.es; Tel.: +34-013-476-843
}

Received: 15 March 2018; Accepted: 26 March 2018; Published: 28 March 2018

\begin{abstract}
Plantations with alien forest species could be a major way for invasive plant and animal species to become introduced and naturally established in a territory, but the sensitivity of plantations with native forest species to invasive plant and animal species is still unknown. This paper studies the probability of the presence and the richness of invasive species of three different taxa (plants, birds, and mammals) in pine forests of southwestern Europe. To do so, the relative contribution from natural and planted forests is analysed to explain the presence and the richness of invasive species in 3950 cells $(10 \mathrm{~km} \times 10 \mathrm{~km})$ covering Spain after controlling for the possible effects of variables related to geography, climate, land use, landscape, and human pressure on the environment. Our results show that man's influence on the establishment of invasive species is notable. However, those forests that are the most intensely managed by man, such as pine plantations with native species, seem less susceptible to the establishment and propagation of invasive species. Reasons may be found in those planted pine forests being closely monitored, controlled, and managed by man. Therefore, it is argued that efforts related to the early warning systems of invasive species should be focused on natural pine forests.
\end{abstract}

Keywords: alien species; forest inventory; forest management; invasibility; monitoring

\section{Introduction}

Around the globe, biological invasions threaten biodiversity [1-4]. They are a costly environmental problem, affecting crops and livestock production, transmitting diseases, choking river systems, etc. and also leading to millions of dollars annually in efforts to control them [5-7]. They can be especially costly to natural resource based livelihoods in developing countries, which often lack the operational capabilities to prevent them or mitigate their impacts [8]. The numbers of newly established alien species are still increasing [9] with socio-economical, technological, and environmental changes leading to novel patterns of plant introductions and invasionopportunities [10,11]. As a result, prevention, monitoring, invasions and early detection of new alien species naturalisations are seen as priorities for management [12-15]. However, predicting the invasion potential of species is complex as it depends of context specific information linked to the transport mode of a species, the number of introduced species, the frequency of introduction, the time that has elapsed since a species was first introduced, and the actual biology and ecology of an introduced species (e.g., [2,12,16-19]). 
In this paper, we deepen our understanding of biological invasions by focusing on the socioeconomic factors that affect the invasibility of one of most anthropised landscapes, planted forest with respect to their natural counterpart. Thus, we explore the invasibility of the recipient ecosystems, defined as the vulnerability of a habitat and the associated biological community to invasion (e.g., $[20,21])$. We studied the presence and richness of invasive alien species of three different taxa: plants, birds, and mammals, across pine forest landscapes in Spain. We followed current literature that has studied the influence of geography, climate, the diversity of the native species, and anthropogenic pressures related to land uses, fragmentation, fires disturbances, that impact on the invasibility of ecosystems due to their effects on various elements of the composition, structure, functioning and pattern of landscapes [18,22-26]. Land use change is central to the establishment and spread of invasions. More modified habitats such as urban areas, agricultural, ground, pastures and exotic forestry plantations have been shown to influence the presence and abundance of plants and animal invasive species (e.g., [24,27]). Moreover, as urbanisation and agricultural land use increase, forest landscapes are becoming increasingly fragmented and surrounded by human settlements, creating more edge effects, that influence environmental conditions, and consequently biodiversity loss and abundance of alien species (e.g., [28,29]). The risk posed by invasions is sensitive also to the increasing urban-wildland interfaces due to a higher propagule pressure in these areas (e.g., from suburban gardens), and their associated higher level of human disturbances for their proximity to human-related activities, density of roads and railways, for example, that often lead to the creation of open areas, removing competitors and dispersing propagules (e.g., [30,31]). The incidence of disturbances, such as forest fires, has been shown to be greater at urban-wildland interface (e.g., [32-34]), and fires have also been identified as a key factor that explains the spread of invasions (e.g., $[23,35])$.

We contribute to this literature by conducting a broad scale analysis, at the national level and using different taxa (preventing bias from the specific ecology of just a few species) where we evaluated the role of planted native forest on invasibility. Right now, no evidence has been reported about what role plantations with native forest species play in the vulnerability to invasive species, despite the strong evidence that plantations with alien species, specifically planted alien pine forests, can promote the introduction and natural establishment of invasive species [36-39]. Our hypothesis is that planted forests with native pine species, as anthropised systems are more intensely transformed, managed, and manipulated by man, than natural regenerated native pine forest, and may be less susceptible to the establishment and propagation of invasive species, precisely due to the fact that they are more closely monitored [14,15]. Our analysis focuses in Spain because most of pine forests are composed of native pine species, either naturally regenerated or planted. Moreover, there is information available at the national scale on the origin of pine forest based on the study of Alia et al. [40], which distinguishes forest provenance regions and planted from natural pine forests, attending to historical and genetic data. Also, in this paper, we evaluate further the role of native species biodiversity as an indicator of the level of acceptance of species diversity by a territory. This is an area where the literature shows opposite results. On one hand, species-rich systems may be less susceptible to invasion due to species and function saturation; on the other hand, species-poor systems may not provide good conditions to invasive species following the 'the rich get richer' acceptance hypothesis (e.g., [24,41]). Furthermore, our analysis informs forest management by evaluating the implications that increased urbanisation and landscape fragmentation have on the risk of invasions in pine forests due to associated edge effect and an increasing wildland-urban interface.

\section{Materials and Methods}

This work studies the richness of invasive alien species of three different taxa: plants, birds, and mammals. These taxa have been studied extensively in literature and there is a great volume of data available at the regional level (e.g., [42,43]). Information on the number of invasive alien species was recorded by the Spanish Inventory of Terrestrial Species (Ministry of Agriculture, Food and 
Environment), the Atlas of Invasive Allochthonous Plants in Spain [44], both at the scale of a $10 \times 10-\mathrm{km}$ UTM grid, and the Spanish catalog of invasive alien species (Real Decreto 630/2013, 2nd of August). The list of invasive alien species used in this study (Table 1) was selected by focusing on those species that are found in the $10 \times 10-\mathrm{km}$ grids where the coverage of pine forest (natural or planted) exceeds $50 \%$ according to the Spanish Forestry Map (scale 1:50,000; [45,46]), i.e., of 5335 grids that cover the Spanish territory, 653 were used to determine the list of invasive species. This was done in order to focus on those alien species that were most likely to occupy pine forests, i.e., more likely to depend on this type of vegetation.

Table 1. List of invasive alien species used in this study. Presence of the species in the study area is given (cell $=10 \times 10-\mathrm{km}$ ). Those species present in cells where PINE COVER exceeds $50 \%$ were selected.

\begin{tabular}{|c|c|c|c|}
\hline Summary & $\begin{array}{c}>50 \% \text { of Cell Is } \\
\text { Pine Cover }\end{array}$ & $\begin{array}{l}\text { Pine Cover Is } \\
\text { Present in the Cell }\end{array}$ & $\begin{array}{l}\text { All the Cells in the } \\
\text { Spanish Iberian } \\
\text { Peninsula }\end{array}$ \\
\hline \multicolumn{4}{|c|}{ Plant species } \\
\hline Acacia dealbata Link & 63 & 222 & 235 \\
\hline Agavea americana $\mathrm{L}$. & 39 & 227 & 317 \\
\hline Ailanthus altissima (Miller) Swingle. & 39 & 201 & 250 \\
\hline Araujia sericifera Brot. & 19 & 98 & 118 \\
\hline Buddleja davidii Franchet. & 28 & 103 & 107 \\
\hline Carpobrotus edulis (L.) N. E. Br. & 27 & 121 & 155 \\
\hline Cortaderia selloana Asch. \& Graebn. & 11 & 75 & 81 \\
\hline Cylindropuntia imbricata Haw. & 1 & 3 & 6 \\
\hline Elodea canadensis Michx. & 2 & 11 & 14 \\
\hline Fallopia baldschuanica (Regel) Holub & 17 & 73 & 87 \\
\hline Nicotiana glauca Graham & 15 & 116 & 165 \\
\hline Opuntia dillenii (Ker-Gawler) Haw. & 4 & 17 & 24 \\
\hline Opuntia ficus-indica L. (Mill) & 59 & 320 & 509 \\
\hline Oxalis pes-caprae L. & 18 & 195 & 295 \\
\hline Pennisetum setaceum (Forssk.) Chiov. & 1 & 4 & 5 \\
\hline Senecio inaequidens DC. & 2 & 15 & 15 \\
\hline Spartina patens (Ait.) Muhl & 10 & 37 & 49 \\
\hline Tradescantia fluminensis Velloso & 2 & 19 & 23 \\
\hline \multicolumn{4}{|c|}{ Bird species } \\
\hline Amandava amandava $\mathrm{L}$. & 1 & 32 & 73 \\
\hline Estrilda astrild L. & 13 & 78 & 124 \\
\hline Euplectes orix L. & 1 & 2 & 4 \\
\hline Myiopsitta monachus Boddaert. & 12 & 124 & 171 \\
\hline Psittacula krameri Scopoli & 3 & 55 & 82 \\
\hline Streptopelia risoria L. & 1 & 16 & 26 \\
\hline \multicolumn{4}{|c|}{ Mammal species } \\
\hline Ammotragus lervia Pallas & 28 & 94 & 103 \\
\hline Neovison vison Schreber & 112 & 563 & 621 \\
\hline Myocastor coipus Molina & 1 & 19 & 21 \\
\hline Number of cells & 653 & 3950 & 5335 \\
\hline Number of different Plants & 18 & 27 & 27 \\
\hline Number of different Birds & 6 & 15 & 16 \\
\hline Number of different Mammals & 3 & 4 & 4 \\
\hline
\end{tabular}

Data sources and descriptive of variables included in the models are shown in Table 2. We assemble data on total counts of invasive plants (N_IP), richness of invasive birds (N_IB), and richness of invasive mammals (N_IM) for the 3950 grids that have pines according to the Spanish Forestry Map, which include the following species: Pinus pinaster Ait. (present in 1421 grids); Pinus halepensis Mill. (1257 grids); Pinus sylvestris L. (966 grids); Pinus nigra Am. (949 grids); Pinus pinea 
L. (635 grids); Pinus radiata D. Don. (340 grids); and Pinus uncinata Mill. (120 grids). We acknowledge that Pinus radiata is an alien species that has always been planted. It was considered here for completeness of the database and a best representation of these pine ecosystems in Spain. Excluding this species has negligible effect on results.

As explanatory variables, we consider a number of topographic, climatic and societal factors that may influence landscape invasibility. Overall, the analysis focuses on anthropogenic pressures (e.g., $[18,22-24,26,40,47])$, using variables related to land uses, fragmentation, fire disturbances, population density potential, density of roads and railways and the origin of the pine forest which distinguishes between naturally regenerated or planted forests (see variables in Table 2). The use of the variable pine forest type (which describes the origin of the forest) is justified because Martínez-Jauregui et al. [48] showed that planted native pine forests had a negative influence on bird biodiversity in pine forests, but no similar analysis has been done for the invasibility of these landscape. Also, our analysis explores the role of indicators of native species biodiversity, for which the relationship with invasion risk is less clear in the literature (e.g., [24,41]). We control for topographic and climatic aspects, as in the Iberian Peninsula, plant invasive species have been positively associated with low slope, short distance to the coastline, and wet and warm continental areas $[18,26,49]$.

The sources and data used are diverse and were collected at different scales: (1) the geographic and orographic variables were calculated based on digital elevation models $(25 \times 25 \mathrm{~m})$ and national topographical maps; (2) the variables related to climate were derived from the models defined by Gonzalo [50] in a 1- $\mathrm{km}^{2}$ grid; (3) land use and coverage used the information available in the Spanish Forest Map (1:50,000); (4) landscape fragmentation index and the interface surface between wildland and urban land were calculated using the CORINE Land Cover cartography from 2012 (CLC12) (European Environment Agency); (5) the native species biodiversity indicator that expresses the number of pine forest dwelling birds was obtained from the Spanish Breeding Bird Atlas [51] and previous works of the authors on Spanish pine forests [48,52]; (6) biodiversity indicators of native plants, such as richness in the number of trees and shrubs in a territory, were calculated using the Third Spanish Forest Inventory (96,660 stands sampled at a 1-km resolution) [53]; (7) population density potential was calculated for $5 \times 5-\mathrm{km}$ grids [54]; (8) the density of roads and railways was estimated based on the Spanish Topographic Map (1:200,000); (9) density data on the number of forest fires and burned surface area were obtained from the Spanish Forest Fire Report Database of the Ministry of Agriculture and Fisheries, Food, and Environment (data from 1974 to 2008); finally, (10) historical and genetic data for classifying pine forest patches as either planted or natural were obtained based on Alía et al. [40]. ArcGIS ${ }^{\circledR}$ software (Esri Inc., Redlands, CA, USA) by Esri was used to process all the information and adapt it to the same $10 \times 10-\mathrm{km}$ UTM scale.

A Hurdle model was used for evaluating the invasibility of pine forest landscape to each taxon. This approach was selected because variables that express the richness of invasive alien species of plants, birds, and mammals have many data with a value of zero. The analysis includes the interaction between the planted condition of native pines species and the location variable. This interaction is justified since plantations of the northwestern part of the Iberian peninsula (the purpose of which is more for production) and plantations of the southeastern part of the Iberian peninsula (which have a more restorative purpose) have different effects on the biodiversity associated with natural and planted pine forests [52]. The Hurdle model that is used ("pscl" library in R 3.3.1-software, [55,56]) has two components: a first component that models the absence and presence of invasive alien species (binomial with a logit link) and a second component that models the quantities truncated to the fact that the value of the richness of invasive alien species is positive (truncated poisson with a log link). The models were defined using only the non-colinear variables of Table 1 (Pearson matrix, with a threshold of rho $=0.7$ ) that provided the best explanation of the dependent variable (the following are excluded from the analyses: ALTI, SLOP, OCONIF COVER, POT_POBL). All the variables used in the analyses have been standardised (by subtracting the sample means and dividing by the standard deviations). The models have been simplified using the R 3.1.2 step tool (which removes the variables 
that do not contribute significantly to giving greater explanatory value to the model with a backward direction, 1000 steps, and $k=2$ used as the parameters, which are the default settings).

Table 2. Description of the variables used in the analysis $(N=395010 \times 10$ UTM cells).

\begin{tabular}{|c|c|c|c|}
\hline & Definition of the Variables Used in the Analysis & Mean (Stand. Dev.) & Source \\
\hline \multicolumn{4}{|c|}{ DEPENDENT VARIABLES } \\
\hline N_IP & No. of invasive plant species & $0.470(1.070) ; \max =10$ & 1 \\
\hline$N \_I B$ & No. of invasive bird species & $0.077(0.364) ; \max =5$ & 2 \\
\hline$N \_M$ & No. of invasive mammal species & $0.171(0.379) ; \max =2$ & 2 \\
\hline \multicolumn{4}{|c|}{ EXPLANATORY VARIABLES } \\
\hline \multicolumn{4}{|c|}{ Geographic coordinates } \\
\hline LONG & Longitude (UTM) & $466,516.7(225,584.1)$ & 3 \\
\hline$L A T$ & Latitude (UTM) & $4,499,647(216,419)$ & 3 \\
\hline \multicolumn{4}{|l|}{ Topography } \\
\hline ALTI & Height above sea level (m): Average cell altitude & $730.400(396.783)$ & 3 \\
\hline SLOP & Slope $(\mathrm{m}):$ Average cell slope & $10.323(6.116)$ & 3 \\
\hline WATER_LINE & $\begin{array}{l}\text { Line density of river channels, canals, reservoir coasts, lagoons, etc. } \\
\text { and of the sea }\left(\mathrm{m} / \mathrm{km}^{2}\right)\end{array}$ & $472.516(213.730)$ & 4 \\
\hline SEA_DIST & Mean distance to the sea as from a raster of distances of $1 \times 1 \mathrm{~km}$ & $122,047.5(87,699.32)$ & 4 \\
\hline \multicolumn{4}{|l|}{ Climate } \\
\hline PREC & Mean annual precipitation (mm) & $750.762(358.772)$ & 5 \\
\hline TEMP & Mean annual temperature $\left({ }^{\circ} \mathrm{C}\right)$ & $12.760(2.666)$ & 5 \\
\hline \multicolumn{4}{|c|}{ Landscape and land cover } \\
\hline PINE COVER & Pine cover in the cell (ha) & $2171.677(2271.087)$ & 6 \\
\hline OCONIF COVER & Cover of other conifers in the cell (ha) & $2450.856(2355.639)$ & 6 \\
\hline EUC COVER & Eucalyptus spp. cover in the cell (ha) & $256.544(897.677)$ & 6 \\
\hline OBROADL COVER & Other broadleaf cover (different from Eucalyptus spp.) in the cell (ha) & $3018.010(2304.771)$ & 6 \\
\hline SHRUB COVER & Shrub land cover in the cell (ha) & $944.394(1259.084)$ & 6 \\
\hline G P COVER & Ground and pasture land use cover in the cell (ha) & $371.562(860.673)$ & 6 \\
\hline AGR COVER & Agriculture land use cover in the cell (ha) & $3318.305(2719.106)$ & 6 \\
\hline URBAN COVER & Urban land use cover in the cell (ha) & $166.011(437.988)$ & 6 \\
\hline WATER COVER & Water land use cover in the cell (ha) & $86.825(268.477)$ & 6 \\
\hline OTHER COVER & Other land use cover in the cell (ha) & $286.549(541.687)$ & 6 \\
\hline FRAG & $\begin{array}{l}\text { Landscape Fragmentation index based on CLC12 (EEA, 2016). For the } \\
\text { calculation thereof, the } 44 \text { initial classes were reclassified into } 5 \text { classes: } \\
\text { Artificial, Homogeneous agrarian, Heterogeneous agrarian, Forestry, } \\
\text { and Natural Remainder }\end{array}$ & $0.014(0.006)$ & 6 \\
\hline I_UF & Density of the Wildland-Urban Interface $\left(\mathrm{m} / \mathrm{km}^{2}\right)$ & $100.511(181.549)$ & 6 \\
\hline$I_{-} A N$ & Density of the Anthropogenic Interface $\left(\mathrm{m} / \mathrm{km}^{2}\right)$ & $2257.520(1582.053)$ & 6 \\
\hline \multicolumn{4}{|c|}{ Forest diversity of native species } \\
\hline$B D$ & Bird diversity: total number of pine dwelling forest birds in the cell. & $21.300(7.200)$ & 7 \\
\hline$T D$ & $\begin{array}{l}\text { Tree diversity: mean number of different trees from forest inventory } \\
\text { stands available in the cell }\end{array}$ & $13.509(9.796)$ & 8 \\
\hline$S D$ & $\begin{array}{l}\text { Shrub diversity: mean number of different shrubs from forest inventory } \\
\text { stands available in the cell }\end{array}$ & $4.431(2.091)$ & 8 \\
\hline \multicolumn{4}{|c|}{ Human settlement and other human-induced landscape modification indicators } \\
\hline POP & Weighted sum of the 1998 Population Potential, $5 \times 5-\mathrm{km}^{2}$ grid [54] & $13,758.730(57,480.380)$ & \\
\hline TRANSPORT & Density of roads and railroads by grid surface area $\left(\mathrm{m} / \mathrm{km}^{2}\right)$ & $387.426(223.657)$ & 4 \\
\hline N_FIRE & $\begin{array}{l}\text { Density of the number of fires between } 1974 \text { and } 2008\left(\mathrm{No} . / \mathrm{km}^{2}\right) \text { in a } \\
10 \times 10 \text { grid }\end{array}$ & $0.803(1.906)$ & 9 \\
\hline S_FIRE & $\begin{array}{l}\text { Density of burned surface area between } 1974 \text { and } 2008\left(\mathrm{Ha} / \mathrm{km}^{2}\right) \text { based } \\
\text { on a } 10 \times 10 \text { grid }\end{array}$ & $13.223(28.899)$ & 9 \\
\hline PLANT & $\begin{array}{l}\text { Pine forest type: \% of area pine planted with respect to the total pine } \\
\text { forest area }\end{array}$ & $0.666(0.408)$ & 10 \\
\hline
\end{tabular}

Source: (1) Atlas of Invasive Allochthonous Plants in Spain [44]; (2) Spanish Inventory of Terrestrial Species (Ministry of Agriculture, Food and Environment, 2015); (3) Digital elevation model (IGN, $25 \times 25$ m); (4) Spanish Topographic Map (IGN, 1:200,000); (5) Climate models of [50]; (6) Spanish Forest Map (1:50,000); (7) Martínez-Jauregui et al. [48]; (8) Third Spanish Forest Inventory [53]; (9) Spanish Forest Fire Report Database; (10) Regions of provenance of forestry species [40]. 


\section{Results}

Table 3 shows that the condition of being a planted pine forest contributes to explaining the presence of invasive species and that this explanation varies geographically in all the taxa. Conversely, the characteristic of being a planted pine forest explains the richness of invasive species only for the case of invasive alien plants, and it is not significant for invasive birds and mammals.

Table 3. Estimates, Standard error, and Significance of the Hurdle model fitted to invasive Plant, Bird, and Mammal species.

\begin{tabular}{|c|c|c|c|c|c|c|}
\hline & \multicolumn{2}{|c|}{ PLANTS } & \multicolumn{2}{|c|}{ BIRDS } & \multicolumn{2}{|c|}{ MAMMALS } \\
\hline & $\begin{array}{l}\text { Zero Hurdle } \\
\text { Model } \\
\text { Coefficients }\end{array}$ & $\begin{array}{c}\text { Count } \\
\text { Model } \\
\text { Coefficients }\end{array}$ & $\begin{array}{c}\text { Zero Hurdle } \\
\text { Model } \\
\text { Coefficients }\end{array}$ & $\begin{array}{c}\text { Count } \\
\text { Model } \\
\text { Coefficients }\end{array}$ & $\begin{array}{l}\text { Zero Hurdle } \\
\text { Model } \\
\text { Coefficients }\end{array}$ & $\begin{array}{c}\text { Count } \\
\text { Model } \\
\text { Coefficients }\end{array}$ \\
\hline INTERCEPT & -1.56 * & -1.30 * & $-4.40 *$ & $-2.16^{*}$ & $-2.22 *$ & $-13.17 *$ \\
\hline LONG & 0.20 * & 0.19 * & $0.49^{*}$ & 0.30 & 0.28 * & 0.55 \\
\hline$L A T$ & 0.24 * & $0.27 *$ & & & 0.17 & 2.22 \\
\hline WATER_LINE & 0.24 * & 0.07 * & & & & \\
\hline SEA_DIST & -0.97 * & $-1.21 *$ & 0.37 * & 0.21 & 0.85 * & -1.02 \\
\hline PREC & 0.32 * & -0.07 & 0.44 * & 0.06 & & \\
\hline TEMP & $0.77^{*}$ & $0.31 *$ & $1.57^{*}$ & 0.62 & 0.39 * & 4.12 \\
\hline $\begin{array}{c}\text { PINE } \\
\text { COVER }\end{array}$ & & & & & 0.20 * & -0.46 \\
\hline EUC COVER & 0.19 * & -0.08 & 0.21 * & 0.03 & 0.13 * & -2.43 \\
\hline $\begin{array}{c}\text { OBROADL } \\
\text { COVER }\end{array}$ & & & $-0.45^{*}$ & -0.51 * & & \\
\hline $\begin{array}{l}\text { SHRUB } \\
\text { COVER }\end{array}$ & & & & & $0.19 *$ & 1.74 \\
\hline GP COVER & 0.24 * & 0.00 & $-0.45^{*}$ & -0.47 & 0.25 * & -2.66 \\
\hline AGR COVER & & & 0.12 & $-0.71 *$ & $0.47^{*}$ & -2.94 \\
\hline $\begin{array}{l}\text { URBAN } \\
\text { COVER }\end{array}$ & $0.57^{*}$ & $0.05 *$ & $0.39 *$ & 0.02 & $0.11 *$ & -1.16 \\
\hline$F R A G$ & 0.22 * & 0.04 & 0.16 & 0.42 * & & \\
\hline I_UF & 0.03 & 0.06 & 0.34 * & 0.05 & 0.32 * & 0.22 \\
\hline$I \_A N$ & $-0.19 *$ & -0.25 * & -0.42 * & -0.50 & & \\
\hline$B D$ & 0.18 * & 0.02 & $0.58 *$ & -0.01 & 0.54 * & 1.66 \\
\hline$T D$ & & & -0.34 * & -0.01 & 0.38 * & 0.30 \\
\hline$S D$ & 0.22 * & $0.08^{*}$ & & & -0.23 * & -0.84 \\
\hline TRANSPORT & & & & & 0.18 * & 0.91 \\
\hline N_FIRE & 0.37 * & 0.06 & 0.44 * & 0.22 & & \\
\hline S_FIRE & & & -0.13 & -0.29 & & \\
\hline PLANT & -0.33 * & -0.21 * & 0.18 & 0.17 & -0.14 & 0.28 \\
\hline LONG:PLANT & -0.01 & 0.17 * & $-0.45^{*}$ & -0.21 & $-0.32 *$ & -0.52 \\
\hline LAT:PLANT & -0.27 * & -0.16 * & & & $0.45^{*}$ & -0.05 \\
\hline
\end{tabular}

All variables are standardized (by subtracting the sample means and dividing by the standard deviations). An interaction between two variables is represented by ":" (e.g., LONG:PLANT and LAT:PLANT). Significant variables (alpha $=0.05)$ is represented by an asterisk "*".

Hence, the presence of planted pine forests has a negative and significant influence on the establishment and abundance of invasive alien plants, after having corrected for other factors that regularly have an influence on the richness of invasive plants (such as climate characteristics, the composition and structure of the landscape, and the intensity of human-driven land uses and disturbances). Moreover, planted pine forests were found to have an indirect influence on the presence of invasive alien birds and mammals, as their interaction with the geographic variables was significant.

Some factors that are common to the three taxa and that have a significant influence on the presence of exotic species are longitude (the farther to the east, the greater the probability that invasive species will be present), temperature (higher temperatures favour invasive species), the presence of eucalyptus plantations (whose quantity of hectares favours the presence of invasive species), 
the hectares of urban use (which also favours the presence of invasive species), and the richness of native bird species (which is significantly and positively related to the establishment of invasive species). In addition to the aforementioned variables, other variables have an influence on the presence of invasive species in the various taxa. For example, the distance to the sea has a negative influence on the presence of invasive plants, but it has a positive influence on the presence of invasive birds and mammals; the number of fires has a positive influence on the presence of invasive plants and birds; the density of the wildland-urban interface has a positive influence on the presence of birds and mammals; etc. (see Table 3).

The quantity of invasive alien plants (conditioned by the fact that invasive plants are present) is explained by practically the same variables and in the same directions as the presence of invasive species, which includes the fact that planted pine forests house a lower number of invasive plants. The same does not hold true for quantities of invasive birds and mammals. In both taxa, the majority of the preceding variables are not significant, and the condition of being a planted or natural pine forest is not significant.

\section{Discussion}

The results corroborate our initial hypothesis, according to which we pose that the intensity of human presence in a territory has a notable influence on the presence of alien species (specifically, urban cover and the wildland-urban interface), as it has already been suggested by other authors (e.g., $[18,22,26])$. The analysis compares invasibility in planted pine systems with those that are naturally regenerated, and show that the sensitivity to invasion of planted systems is lower. This effect is especially notable in invasive plants. Our analysis therefore contrasts with earlier evidence that shows that plantations can promote invasive species [36-39]. This result may be explained by the fact that we focus mainly on plantations with native pine species (with the exception of Pinus radiata). Moreover, they can also be explained because planted forests might benefit from early warning systems due to the various silvicultural operations and planning that often take place in these forests [15]. Weaker evidence was found with respect to invasion of birds or mammals, probably because they are more weakly linked to the characteristics of the studied habitat due to being species that move.

This study corroborates and generalises, for a greater number of taxa, some of the relationships found for invasive species on the Iberian Peninsula. The geographic variables show that, in general, in the eastern part of the Iberian Peninsula, it is more probable that an invasive species will become established (regardless of the taxon) $[18,22,26]$. Moreover, there is a greater probability of presence and richness in terms of the number of alien plants and a lower probability of the presence of birds and mammals in areas that are close to the sea $[18,26]$. Climate also plays an important role in the acceptance of an invasive species by a territory. Thus, we found that a higher mean annual temperature (for all taxa) and a greater mean annual precipitation for plants and birds favoured the presence of invasive species $[18,22,26]$. Regarding the structure of the landscape, our results confirm that human pressure on the environment has a significant influence on the establishment and richness of invasive species [22,26]. Within this context, even the hectares of plantations with alien species (such as eucalyptus) have a positive effect on the presence of invasive alien species from all taxa. Our explanation is that the managers of these plantations with eucalyptus, given that it is an alien plant and requires little management, could be less concerned about the establishment of some alien species than in plantations that have native species. However, note that their influence is not significant for models of richness or quantity of species, just for presence. Finally, our analyses confirm that greater acceptance of native species could be related to the same capacity to accept invasive species; ([41] agree with our results, but $[22,24]$ do not).

The fact that geographic and climate conditions and the presence of humans have an influence on the quantity of invasive species in a location is only observed for invasive plants, while these variables are not significant for birds and mammals. This circumstance could be explained by other variables 
that are not considered here, such as hunting, the location of farms where these species are raised, or the origin and ecology of the invasive species themselves [12,17,18,57].

\section{Conclusions}

Plantations have been shown to have a negative effect on biodiversity by creating uniformity in the composition and structure of forests [48,58-60]. However, this research provides some evidence that in these anthropised systems, the probability that an invasive species might become established is lower, with the potential positive benefits on the overall biodiversity. Our work also suggests that early warning systems of invasive species should be focused on natural pine forests, because they have a higher probability of invasive species being established than pine plantations. We detected general patterns for pine forests. However, specific research is necessary among pine species and forest composition and structure [52,61] in order to make specific management recommendations according to forest characteristics. Estimating the benefits of integrating an invasive species early warning system in forest management is an issue that requires further study.

Acknowledgments: This study is framed within the project INIA ref. RTA2013-00048-C03-01 funded by the Spanish Ministry of Economy and Competitiveness. Financial support from the University of Valladolid (Plan de Movilidad de Personal Investigador, 2017) is also acknowledged.

Author Contributions: M.M.-J. and M.S. conceived and designed the study; J.M.-F. obtained the data and improved the variables used; M.M.-J. analyzed the data; M.M.-J., M.S., J.M.-F. and J.T. discussed the results and wrote the paper.

Conflicts of Interest: The authors declare no conflict of interest.

\section{References}

1. Molnar, J.L.; Gamboa, R.L.; Revenga, C.; Spalding, M.D. Assessing the global threat of invasive species to marine biodiversity. Front. Ecol. Environ. 2008, 6, 485-492. [CrossRef]

2. Pyšek, P.; Jarošík, V.; Hulme, P.E.; Kühn, I.; Wild, J.; Arianoutsou, M.; Bacher, S.; Chiron, F.; Didžiulis, V.; Essl, F. Disentangling the role of environmental and human pressures on biological invasions across Europe. Proc. Natl. Acad. Sci. USA 2010, 107, 12157-12162. [CrossRef] [PubMed]

3. Fei, S.; Phillips, J.; Shouse, M. Biogeomorphic impacts of invasive species. Annu. Rev. Ecol. Evol. Syst. 2014, 45, 69-87. [CrossRef]

4. Doherty, T.S.; Glen, A.S.; Nimmo, D.G.; Ritchie, E.G.; Dickman, C.R. Invasive predators and global biodiversity loss. Proc. Natl. Acad. Sci. USA 2016, 113, 11261-11265. [CrossRef] [PubMed]

5. Ricciardi, A.; Palmer, M.E.; Yan, N.D. Should biological invasions be managed as natural disasters? BioScience 2011, 61, 312-317. [CrossRef]

6. Paini, D.R.; Sheppard, A.W.; Cook, D.C.; De Barro, P.J.; Worner, S.P.; Thomas, M.B. Global threat to agriculture from invasive species. Proc. Natl. Acad. Sci. USA 2016, 113, 7575-7579. [CrossRef] [PubMed]

7. Vilà, M.; Hulme, P.E. Impact of Biological Invasions on Ecosystem Services; Springer: Berlin/Heidelberg, Germany, 2017; Volume 12, ISBN 3-319-45121-9.

8. Early, R.; Bradley, B.A.; Dukes, J.S.; Lawler, J.J.; Olden, J.D.; Blumenthal, D.M.; Gonzalez, P.; Grosholz, E.D.; Ibañez, I.; Miller, L.P.; et al. Global threats from invasive alien species in the twenty-first century and national response capacities. Nat. Commun. 2016, 7, 12485. [CrossRef] [PubMed]

9. Seebens, H.; Blackburn, T.M.; Dyer, E.E.; Genovesi, P.; Hulme, P.E.; Jeschke, J.M.; Pagad, S.; Pyšek, P.; Winter, M.; Arianoutsou, M.; et al. No saturation in the accumulation of alien species worldwide. Nat. Commun. 2017, 8, 14435. [CrossRef] [PubMed]

10. Turbelin, A.J.; Malamud, B.D.; Francis, R.A. Mapping the global state of invasive alien species: Patterns of invasion and policy responses. Glob. Ecol. Biogeogr. 2017, 26, 78-92. [CrossRef]

11. Ricciardi, A.; Blackburn, T.M.; Carlton, J.T.; Dick, J.T.; Hulme, P.E.; Iacarella, J.C.; Jeschke, J.M.; Liebhold, A.M.; Lockwood, J.L.; MacIsaac, H.J. Invasion science: A horizon scan of emerging challenges and opportunities. Trends Ecol. Evol. 2017, 32, 464-474. [CrossRef] [PubMed]

12. Kolar, C.S.; Lodge, D.M. Progress in invasion biology: Predicting invaders. Trends Ecol. Evol. 2001, 16, $199-204$. [CrossRef] 
13. Cassey, P.; Blackburn, T.M.; Russell, G.J.; Jones, K.E.; Lockwood, J.L. Influences on the transport and establishment of exotic bird species: An analysis of the parrots (Psittaciformes) of the world. Glob. Chang. Biol. 2004, 10, 417-426. [CrossRef]

14. Cacho, O.J.; Hester, S.M. Deriving efficient frontiers for effort allocation in the management of invasive species. Aust. J. Agric. Resour. Econ. 2011, 55, 72-89. [CrossRef]

15. Hester, S.M.; Cacho, O.J. The contribution of passive surveillance to invasive species management. Biol. Invasions 2017, 19, 737-748. [CrossRef]

16. Duncan, R.P.; Blackburn, T.M.; Sol, D. The ecology of bird introductions. Annu. Rev. Ecol. Evol. Syst. 2003, 34, 71-98. [CrossRef]

17. Pyšek, P.; Richardson, D.M. Traits associated with invasiveness in alien plants: Where do we stand? In Biological Invasions; Springer: Berlin/Heidelberg, Germany, 2008; pp. 97-125.

18. Gassó, N.; Sol, D.; Pino, J.; Dana, E.D.; Lloret, F.; Sanz-Elorza, M.; Sobrino, E.; Vilà, M. Exploring species attributes and site characteristics to assess plant invasions in Spain. Divers. Distrib. 2009, 15, 50-58. [CrossRef]

19. Keller, R.P.; Geist, J.; Jeschke, J.M.; Kühn, I. Invasive species in Europe: Ecology, status, and policy. Environ. Sci. Eur. 2011, 23, 23. [CrossRef]

20. Richardson, D.M.; Pyšek, P. Plant invasions: Merging the concepts of species invasiveness and community invasibility. Prog. Phys. Geogr. 2006, 30, 409-431. [CrossRef]

21. Dalmazzone, S.; Giaccaria, S. Economic drivers of biological invasions: A worldwide, bio-geographic analysis. Ecol. Econ. 2014, 105, 154-165. [CrossRef]

22. Pino, J.; Font, X.; Carbo, J.; Jové, M.; Pallares, L. Large-scale correlates of alien plant invasion in Catalonia (NE of Spain). Biol. Conserv. 2005, 122, 339-350. [CrossRef]

23. Keeley, J.E. Fire management impacts on invasive plants in the western United States. Conserv. Biol. 2006, 20, 375-384. [CrossRef] [PubMed]

24. Vila, M.; Pino, J.; Font, X. Regional assessment of plant invasions across different habitat types. J. Veg. Sci. 2007, 18, 35-42. [CrossRef]

25. González-Moreno, P.; Pino, J.; Gassó, N.; Vila, M. Landscape context modulates alien plant invasion in Mediterranean forest edges. Biol. Invasions 2013, 15, 547-557. [CrossRef]

26. González-Moreno, P.; Diez, J.M.; Ibáñez, I.; Font, X.; Vilà, M. Plant invasions are context-dependent: Multiscale effects of climate, human activity and habitat. Divers. Distrib. 2014, 20, 720-731. [CrossRef]

27. Pyšek, P.; Bacher, S.; Chytrý, M.; Jarošík, V.; Wild, J.; Celesti-Grapow, L.; Gassó, N.; Kenis, M.; Lambdon, P.W.; Nentwig, W. Contrasting patterns in the invasions of European terrestrial and freshwater habitats by alien plants, insects and vertebrates. Glob. Ecol. Biogeogr. 2010, 19, 317-331. [CrossRef]

28. Krauss, J.; Bommarco, R.; Guardiola, M.; Heikkinen, R.K.; Helm, A.; Kuussaari, M.; Lindborg, R.; Öckinger, E.; Pärtel, M.; Pino, J. Habitat fragmentation causes immediate and time-delayed biodiversity loss at different trophic levels. Ecol. Lett. 2010, 13, 597-605. [CrossRef] [PubMed]

29. Alston, K.P.; Richardson, D.M. The roles of habitat features, disturbance, and distance from putative source populations in structuring alien plant invasions at the urban/wildland interface on the Cape Peninsula, South Africa. Biol. Conserv. 2006, 132, 183-198. [CrossRef]

30. Brothers, T.S.; Spingarn, A. Forest fragmentation and alien plant invasion of central Indiana old-growth forests. Conserv. Biol. 1992, 6, 91-100. [CrossRef]

31. McAfee, B.J.; Nealis, V.; Malouin, C. Invasive alien species at the urban-forest interface. Environments 2006, $34,85$.

32. Lampin-Maillet, C.; Jappiot, M.; Long, M.; Bouillon, C.; Morge, D.; Ferrier, J.-P. Mapping wildland-urban interfaces at large scales integrating housing density and vegetation aggregation for fire prevention in the south of France. J. Environ. Manag. 2010, 91, 732-741. [CrossRef] [PubMed]

33. Herrero-Corral, G.; Jappiot, M.; Bouillon, C.; Long-Fournel, M. Application of a geographical assessment method for the characterization of wildland-urban interfaces in the context of wildfire prevention: A case study in western Madrid. Appl. Geogr. 2012, 35, 60-70. [CrossRef]

34. Chas-Amil, M.; Prestemon, J.; McClean, C.; Touza, J. Human-ignited wildfire patterns and responses to policy shifts. Appl. Geogr. 2015, 56, 164-176. [CrossRef]

35. Hernández, L.; Martínez-Fernández, J.; Cañellas, I.; de la Cueva, A.V. Assessing spatio-temporal rates, patterns and determinants of biological invasions in forest ecosystems. The case of Acacia species in NW Spain. For. Ecol. Manag. 2014, 329, 206-213. [CrossRef] 
36. Richardson, D.M. Forestry trees as invasive aliens. Conserv. Biol. 1998, 12, 18-26. [CrossRef]

37. Essl, F.; Moser, D.; Dullinger, S.; Mang, T.; Hulme, P.E. Selection for commercial forestry determines global patterns of alien conifer invasions. Divers. Distrib. 2010, 16, 911-921. [CrossRef]

38. Dodet, M.; Collet, C. When should exotic forest plantation tree species be considered as an invasive threat and how should we treat them? Biol. Invasions 2012, 14, 1765-1778. [CrossRef]

39. McGregor, K.F.; Watt, M.S.; Hulme, P.E.; Duncan, R.P. What determines pine naturalization: Species traits, climate suitability or forestry use? Divers. Distrib. 2012, 18, 1013-1023. [CrossRef]

40. Alía, R.; Garcia del Barrio, J.M.; Iglesias, S.; Mancha, J.A.; de Miguel, J.; Nicolás, J.L.; Pérez, F.; Sánchez de Ron, D. Regiones de Procedencia de Especies Forestales en España; Organismo Autónomo Parques Nacionales, Ministerio de Medio Ambiente y Medio Rural y Marino: Madrid, Spain, 2009; ISBN 978-84-8014-759-0.

41. Moore, J.; Mouquet, N.; Lawton, J.; Loreau, M. Coexistence, saturation and invasion resistance in simulated plant assemblages. Oikos 2001, 94, 303-314. [CrossRef]

42. Jeschke, J.M.; Strayer, D.L. Invasion success of vertebrates in Europe and North America. Proc. Natl. Acad. Sci. USA 2005, 102, 7198-7202. [CrossRef] [PubMed]

43. Lambdon, P.W.; Pyšek, P.; Basnou, C.; Hejda, M.; Arianoutsou, M.; Essl, F.; Jarošík, V.; Pergl, J.; Winter, M.; Anastasiu, P. Alien flora of Europe: Species diversity, temporal trends, geographical patterns and research needs. Preslia 2008, 80, 101-149.

44. Sanz-Elorza, M.; Sánchez, E.D.D.; Vesperinas, E.S. Atlas de las Plantas Alóctonas Invasoras en España; Dirección General para la Biodiversidad, Ministerio de Medio Ambiente: Madrid, Spain, 2004; ISBN 84-8014-575-7.

45. Vallejo, R. El Mapa Forestal de España Escala 1:50,000 (MFE50) Como Base del Tercer Inventario Forestal Nacional. Available online: http://www.mapama.gob.es/es/desarrollo-rural/temas/politica-forestal/ inventario-cartografia/mapa-forestal-espana/mfe_50.aspx (accessed on 1 June 2017).

46. MAPAMA-Ministerio de Agricultura y Pesca, Alimentación y Medio Ambiente. Mapa Forestal de España a Escala 1:50,000. 1997. Available online: http:/ / www.mapama.gob.es/es/biodiversidad/servicios/bancodatos-naturaleza/informacion-disponible/mfe50.aspx (accessed on 1 June 2017).

47. Muñoz, A.; Real, R. Assessing the potential range expansion of the exotic monk parakeet in Spain. Divers. Distrib. 2006, 12, 656-665. [CrossRef]

48. Martínez-Jauregui, M.; Díaz, M.; de Ron, D.S.; Soliño, M. Plantation or natural recovery? Relative contribution of planted and natural pine forests to the maintenance of regional bird diversity along ecological gradients in Southern Europe. For. Ecol. Manag. 2016, 376, 183-192. [CrossRef]

49. Dullinger, I.; Wessely, J.; Bossdorf, O.; Dawson, W.; Essl, F.; Gattringer, A.; Klonner, G.; Kreft, H.; Kuttner, M.; Moser, D. Climate change will increase the naturalization risk from garden plants in Europe. Glob. Ecol. Biogeogr. 2017, 26, 43-53. [CrossRef] [PubMed]

50. Gonzalo, J. Diagnosis Fitoclimática de la España Peninsular. Actualización y Análisis Geoestadístico Aplicado; Universidad Politécnica de Madrid: Madrid, Spain, 2008.

51. Martí, R.; Del Moral, J.C.; de Ornitología, S.E. Atlas de la aves Reproductoras de España; Dirección General de Conservación de la Naturaleza-Sociedad Española de Ornitología: Madrid, Spain, 2003; ISBN 84-8014-474-2.

52. Martínez-Jauregui, M.; Solino, M.; Díaz, M. Geographical variation in the contribution of planted and natural pine forests to the conservation of bird diversity. Divers. Distrib. 2016, 22, 1255-1265. [CrossRef]

53. Alberdi, I.; Condés, S.; Martínez-Millán, J. Review of monitoring and assessing ground vegetation biodiversity in national forest inventories. Environ. Monit. Assess. 2010, 164, 649-676. [CrossRef] [PubMed]

54. Calvo, J.L.; Pueyo, A.; Jover, J.M. Potenciales Demográficos, en Atlas Nacional de España, Sección IV, Grupo 14b; MOPT-IGN: Madrid, Spain, 1992.

55. Zeileis, A.; Kleiber, C.; Jackman, S. Regression models for count data in R. J. Stat. Softw. 2008, $27,1-25$. [CrossRef]

56. Team, R.C. R: A Language and Environment for Statistical Computing; R Foundation for Statistical Computing: Vienna, Austria, 2016. Available online: http:/ / www.R-project.org/ (accessed on 15 March 2018).

57. Carpio, A.J.; Guerrero-Casado, J.; Barasona, J.A.; Tortosa, F.S.; Vicente, J.; Hillström, L.; Delibes-Mateos, M. Hunting as a source of alien species: A European review. Biol. Invasions 2017, 19, 1197-1211. [CrossRef]

58. Gómez-Aparicio, L.; Zavala, M.A.; Bonet, F.J.; Zamora, R. Are pine plantations valid tools for restoring Mediterranean forests? An assessment along abiotic and biotic gradients. Ecol. Appl. 2009, 19, 2124-2141. [CrossRef] 
59. Ruiz-Benito, P.; Gómez-Aparicio, L.; Zavala, M.A. Large-scale assessment of regeneration and diversity in Mediterranean planted pine forests along ecological gradients. Divers. Distrib. 2012, 18, 1092-1106. [CrossRef]

60. Calladine, J.; Díaz, M.; Reino, L.; Jardine, D.; Wilson, M. Plantations of non-native tree species. In Ecology and Conservation of Forest Birds; Cambridge University Press: Cambridge, UK, 2017.

61. Bonari, G.; Acosta, A.T.; Angiolini, C. Mediterranean coastal pine forest stands: Understorey distinctiveness or not? For. Ecol. Manag. 2017, 391, 19-28. [CrossRef] 